\title{
SCREENING, ISOLATION, AND ANTIBACTERIAL ACTIVITY OF ANTIBIOTIC PRODUCING BACTERIA OBTAINED FROM SAPROPHYTIC SOIL SAMPLES
}

\author{
KAVITHA R*, DHAMODHARAN N, DHIVYA C \\ Department of Pharmaceutics, SRM College of Pharmacy, SRM Nagar, Kanchipuram, Tamil Nadu, India. Email: kavithar2007@gmail.com \\ Received: 03 August 2016, Revised and Accepted: 24 November 2016
}

\begin{abstract}
Objective: The aim of the study was conducted to screen and isolate potential antibiotic producing bacteria from saprophytic soils collected from Potheri and Nandiambakkam.

Methods: Soil was collected aseptically and subjected to serial dilution. Crowded plate technique was used for the isolation of the colony. Totally seven isolates were isolated and were screened for their antibacterial activity. The three isolates (S2A, S2B, and S3A) having better zone of inhibition were selected for morphological, microscopical, and biochemical test to prove their validity. The selected isolates were partially purified. The partially purified samples further screened for antibacterial activity, minimum inhibitory concentration (MIC) and the isolates, which shown good zone of inhibition were subjected to $16 \mathrm{~S}$ rRNA sequencing studies to determine the species.
\end{abstract}

Results: The isolates screened based on size of the zone formed. Best isolate selected by zone of inhibition was subjected to antibacterial activity, morphological, microscopical, and biochemical test, partial purification of three isolates and further screened for antibacterial and MIC. The isolate showed good zone of inhibition compared to others by MIC was selected for 16S rRNA sequencing studies. Genomic DNA extracted from isolate S2B conforms it belongs to Pseudomonas species which is named as Pseudomonas putida 2435.

Conclusion: The research work revealed that the three isolates showed good antibacterial activity against Gram-positive and Gram-negative bacteria. The S2B isolate was confirmed to P. putida 2435 by $16 \mathrm{~S}$ rRNA studies.

Keywords: Isolation of soil microbes, Biochemical characterization, Antimicrobial activity, Minimum inhibitory concentration, 16S rRNA sequencing, Pseudomonas putida.

(C) 2017 The Authors. Published by Innovare Academic Sciences Pvt Ltd. This is an open access article under the CC BY license (http://creativecommons. org/licenses/by/4. 0/) DOI: http://dx.doi.org/10.22159/ajpcr.2017.v10i3.14472

\section{INTRODUCTION}

Antibiotics produced by microorganisms have been very useful for the cure of certain human diseases caused by bacteria, fungi, and protozoa. Total world production of antibiotics is more than one million tons per annum. Due to continuous endeavor made in this field, the antibiotics discovered at present are about 5,500 [1]. With the increasing number of drug-resistant pathogens, particularly the acquired multidrug resistant strains, and serious public health problems have arisen worldwide. Therefore, the need for antimicrobial discovery and better treatments of these infections, particularly in hospitals where antibiotic resistance is immediately life-threatening, is becoming a rapidly growing concern. The study of different environments throughout the world has yielded a lot of antimicrobial agents that are of great value for the treatment of many infectious diseases [2]. There are many other potential antibiotic producing microorganisms present in the soil that have yet to discovered or utilized. Most of the antibiotic producers used today are the soil microbes [3]. In response, there is a renewed interest in discovering novel classes of antibiotics that have different mechanisms of action [4].

As the soil is favorable for the survival of most of the microorganisms, the multi resistant organism will grow rapidly and spread through various modes throughout the soil. Hence, one of the most successful approaches to obtain new types of useful microbial metabolites is to investigate slowly growing or until now simply neglected microorganism from soil. The diversity of soil microorganisms were of great significance as a factor promoting the early discovery of antibiotics. Many types of microorganisms such as molds, bacteria, protozoa and algae, autotrophs, free-living nitrogen fixers, thermopiles, acidophiles, pathogens, and saprophytes. Natural product antimicrobials have been used for centuries by native peoples all around the world but it was not until the late 1800s that people began to search for single compounds that could be used to kill disease-causing bacteria [5].

Bacteria, which are treated with antibiotics, are by far the most common cause of infections related deaths. It is advisable to screen antibiotic producing bacteria as they are very easy to isolate culture and maintain and to improve their strains. Bacteria hold a prominent position as targets in screening program due to their diversity and their proven ability to produce novel antibiotics. Keeping in mind the above-mentioned points, this study deals with the isolation of new strains of bacteria from soil and screening it antimicrobial activity against microbes. Search for new antibiotics effective against multidrug resistant pathogenic bacteria is presently an important area of antibiotic research.

This work was undertaken with an effort to isolate antibiotic producing bacteria from different soil samples of Tamil Nadu, India. And evaluate their antagonistic potentials against some human pathogenic bacteria.

\section{MATERIALS AND METHODS}

Materials

Chemicals, media, and reagents, equipment used for this study were procured from Himedia, SRL, Rankem, Spin Win, Biosafe, Labinda, Riviera, Labomed, Guna Enterprise, Equitron, Thermo-orion, Godrej, India.

\section{Methods}

Collection of soil samples

Sample of soil was collected from the saprophytic soils in north region of Tamil Nadu, India, located at longitude 80.04 and latitude 12.82 in 
map. The samples were taken up to the depth of $20 \mathrm{~cm}$ after removing approximately $3 \mathrm{~cm}$ of the soil surface. About $5 \mathrm{~g}$ of this soil was taken and it was stored in sterile poly bags, sealed tightly and transported immediately to the laboratory.

\section{Bacterial cultures}

The test organisms (Klebsiella pneumonia NCIM2957, Bacillus subtilis NCIM2717, Staphylococcus aureus NCIM5021, Escherichia coli NCIM2810, Pseudomonas aeruginosa NCIM2957, and Streptococcus NCIM2888) were obtained from the National Collection of Industrial Microorganisms, Pune, India.

\section{Culture media}

The cultural media used for testing antimicrobial activity was MuellerHinton agar. The culture media was prepared and sterilized following the manufacturer's instructions.

\section{Preparation of soil sample}

Seven test tubes were taken; $9 \mathrm{ml}$ of phosphate buffer saline was poured in each test tube. The tubes were subject to sterilization in an autoclave, $121^{\circ} \mathrm{C}$ for 15 minutes. Each $1 \mathrm{~g}$ of the soil sample was suspended in $10 \mathrm{ml}$ of phosphate buffer saline and shake vigorously for 2-3 minutes and from the stock solution $1 \mathrm{ml}$ was used to prepare the final volume of $10^{3}-10^{7}$, by serial dilution method. This was done entirely in sterile conditions [1].

\section{Isolation of the microorganism}

Nutrient agar medium was prepared. The medium along with glass Petri dishes was sterilized in an autoclave at $121^{\circ} \mathrm{C}$ for $15-20$ minutes. After sterilization, the media was slowly cooled to $50^{\circ} \mathrm{C} .20 \mathrm{ml}$ of the media was poured into each of these Petri dishes and allowed to solidify the media. Crowded plate technique was used to isolate the antibiotic producing colonies. $0.1 \mathrm{ml}$ of suspension $10^{-3}-10^{-7}$ was used to spread on agar medium aseptically using L-shaped glass rod. For each sample, three plates were used and incubated at $37^{\circ} \mathrm{C}$ for $48 \mathrm{hrs}$. After the period of incubation, the clear zone of inhibitions around the microorganism was observed. The microorganism colony responsible for the clear zone was isolated.

\section{Preservation of soil isolates}

The pure cultures were obtained from selected colonies by repeated subculturing on nutrient agar plates and slants by the method of streaking. Streaking was done using a sterile nichrome loop inside a laminar air flow. The streaks were done; the plates and slants were kept for incubation at $37^{\circ} \mathrm{C}$ for $24 \mathrm{hrs}$. And preserved them by keeping into the refrigerator at $4^{\circ} \mathrm{C}$ and maintained for a longer period by serial subculturing [1].

\section{In-vitro screening of isolates for antagonism}

The seven soil isolates for antibacterial activity screening against the pathogenic test organisms by Agar well diffusion method and Disc diffusion method. In Agar well diffusion method, the test microorganisms were inoculated on Mueller-Hinton Agar plates using sterilized cotton swabs. Wells bored by sterile borer, and $100 \mu$ l of each crude extracts was poured into wells. Plates were incubated at $37^{\circ} \mathrm{C}$ for $24 \mathrm{hrs}[6]$.

In Disc diffusion method, Mueller-Hinton Agar medium was prepared and sterilized followed by proper pouring into Petri plates under aseptic conditions in a laminar air flow. Petri plates were kept for solidification of medium for some time. Antibiotic activities were assayed for the supernatants using Whatman paper discs. The seeded culture of the test microorganisms was plated over the entire surface of agar plates. The medium should not only favor for the growth of the organism but also the production of the antibiotic for the production of the antibiotic by the organism. The paper disc of different isolates was placed in a single plate and incubated at $37^{\circ} \mathrm{C}$ for $24 \mathrm{hrs}$. The antibiotic produced by the organism inhibits the growth of the test microbe, and a dead zone was observed around the discs. $2 \times 10^{8} \mathrm{CFU} / \mathrm{ml}$ culture of belowmentioned microorganisms are taken as a test for the antimicrobial activity of the isolates [7]

\section{Characterization of isolates}

The potential isolates selected from the in-vitro screening were characterized by morphological, biochemical, and physiological methods.

\section{Morphological characterization}

The morphological characters of the selected isolates were studied by inoculating into sterile nutrient agar plate and slant. The media was sterilized and poured into sterile Petri dishes. After solidification, selected isolates were streaked in plates aseptically and incubated at $30^{\circ} \mathrm{C}$ for 5 days. Morphological characters, such as colony characteristics and pigment production, were observed [7].

\section{Microscopical characterization}

The Gram's stain was used to determine positive and negative strain of bacteria with the help of oil immersion microscope at magnification of $\times 100[8]$.

The motility test is performed by preparing wet mount of isolates by Hanging drop method and viewed at $\times 100$ magnification under phase contrast microscope [9].

\section{Biochemical characterization}

After preliminary studies, seven isolates were used for biochemical studies. The various biochemical tests oxidase, catalase, methyl red test, Voges-Proskauer test, citrate utilization test, urease test, triple sugar iron test, gelatin test, and indole test were performed for the identification of the identification of the potent isolates. All the cultures were incubated at $37^{\circ} \mathrm{C} \pm 0.2$ for 6 days $[10,11]$.

\section{Extraction of bioactive compounds}

The culture isolates (S2A, S2B, and S3A) were grown in the production medium and then, down streamed by salting out method using $60 \%$ ammonium sulfate.

The antibacterial activities of the isolates were partial purified by dialysis. The dialysate was purified further by column chromatography using Biogel P30 slurry [12]. The extracted secondary metabolites were used for further studies. The amount of proteins present in the partially purified extracellular crude extracts was estimated by Lowry's method.

\section{Determination of the antibiotic activity of partially purified samples}

Antibacterial activity of partially purified extracellular crude extracts was determined by agar well diffusion method by Muller-Hinton Agar plates. Cell concentration of all the test organisms inoculated MullerHinton agar plates using sterilized cotton swabs. The wells were bored by sterile borer, and $100 \mu \mathrm{l}$ of each crude extract was poured into wells. Plates were incubated at $37^{\circ} \mathrm{C}$ for $24 \mathrm{hrs}$ [5].

Determination of minimum inhibitory concentration (MIC) of isolated antibiotic

A MICs is the lowest concentration of an antimicrobial that inhibits the growth of a microorganism after 18-24 hrs.

Determination of MIC value was carried based on two-fold serial dilution method. A series of six assay tubes for each organism was taken, to the first tube $0.2 \mathrm{ml}$ of stock $(0.1 \mathrm{mg} / \mathrm{ml})$ and $1.8 \mathrm{ml}$ of the seeded broth was added. Then from the first tube, $1 \mathrm{ml}$ was added to $1 \mathrm{ml}$ of seeded broth, likewise, two-fold serial dilutions were conducted up to $6^{\text {th }}$ and incubated at $37^{\circ} \mathrm{C}$ for $24 \mathrm{hrs}$. After incubation, it was 
observed for the lowest concentration of the antibiotic produced by the isolates, which completely inhibited the growth of the microorganisms, and it was noted as the MIC [13]

\section{S rRNA sequencing studies}

The isolates show good zone of inhibition at minimum concentration was selected for $16 \mathrm{~S}$ гRNA sequencing studies.

\section{Isolation of genomic DNA from bacteria}

Bacterial genomic DNA was isolated using the InstaGeneTM matrix genomic DNA isolation Kit, as per the kit instruction below procedure followed. An isolated bacterial colony was picked and suspend in $1 \mathrm{ml}$ of sterile water in a microfuge tube. It was centrifuged for 1 minute at $10,000-12,000 \mathrm{rpm}$ to remove the supernatant. Add $200 \mu \mathrm{l}$ of InstaGene matrix to the pellet and incubated at $56^{\circ} \mathrm{C}$ for 15 minutes. Vortexes at high speed for 10 seconds and the tube were placed in a $100^{\circ} \mathrm{C}$ in heat block or boiling water bath for 8 minutes. The content vortexes at high speed for 10 seconds and then spined at 10,000-12,000 rpm for 2 minutes. In result, $20 \mu \mathrm{l}$ of the supernatant was used per $50 \mu \mathrm{l}$ polymerase chain reaction reaction [14].

\section{PCR amplification}

The S2B organism DNA was amplified by PCR using purified genomic DNA as a template. 16SrRNA Universal primers gene fragment was amplified using MJ Research Peltier Thermal Cycler. Add $1 \mu \mathrm{L}$ of template DNA in $20 \mu \mathrm{L}$ of PCR reaction solution. 27F-AGAGTTTGATCMTGGCTCAG, 1492R-TACGGYTACCTTGTTACGACTT primers were used as primer, and then PCR reaction was performed with below conditions: Initial denaturation $94^{\circ} \mathrm{C}$ for 2 minutes and then 35 amplification cycles at $94^{\circ} \mathrm{C}$ for 45 seconds, $55^{\circ} \mathrm{C}$ for 60 seconds, and $72^{\circ} \mathrm{C}$ for 60 seconds. A final extension at $72^{\circ} \mathrm{C}$ for 10 minutes. DNA fragments were amplified about1, $400 \mathrm{bp}$. Include a positive control (E. coli genomic DNA) and a negative control the PCR [15].

\section{Sequencing and bioinformatics protocol}

Single-pass sequencing was performed on each template using below 16s rRNA universal primers. The 16s rRNA sequence was blast using NCBI blast similarity search tool. The phylogeny analysis of our sequence with the closely related sequence of blast results was performed followed by multiple sequence alignment. The program MUSCLE 3.7 was used for multiple alignments of sequences. The resulting aligned sequences were cured using the program Gblocks $0.91 \mathrm{~b}$. This Gblocks eliminates poorly aligned positions and divergent regions (removes alignment noise) [16,17]. Finally, the program PhyML 3.0 aLRT was used for phylogeny analysis and HKY85 as substitution model.

PhyML was shown to be at least as accurate as other existing phylogeny programs using simulated data while being one order of magnitude faster. PhyML was shown to be at least as accurate as other existing phylogeny programs using simulated data while being one order of magnitude faster. The program Tree Dyn 198.3 was used for tree rendering [18].

\section{RESULTS AND DISCUSSION}

Soil samples from saprophytic soils from saprophytic soil of the north region of Tamil Nadu, India, were chosen as samples for analysis in this study based on the likelihood of the presence of native microorganisms that have not previously been studied by other researchers. Keeping in mind the above-mentioned points, these studies dealt with isolation of new strains of bacteria from soils and screening it for antimicrobial activity against microbes.

These native soil microorganisms have higher probability to produce novel antimicrobial substances. In this study, totally three soil sediments were it for collected from cow farm, goat farm, and refuse dump site and were subjected for isolation and screening by crowded plate technique after serially diluting soil samples using distilled water. Total of seven bacteria isolates were obtained by crowded plate technique and selected for further work (Fig. 1). The selected were tested for their antimicrobial activity by Kirby-Bauer Disc diffusion method (Table 1) and Agar well plate method (Table 2). All the isolates inhibited the growth of pathogenic microorganisms to a varying degree.

Three isolates (S2A, S2B, and S3A) given good zone of inhibition were selected for further testing and characterization. The morphological and microscopical characterization of the three isolates were presented in Tables 3 and 4 and the biochemical characterization of the isolates (S2A, S2B, and S3A) are detailed in Table 5. The protein present in the three isolates was separated by salting out method using $60 \%$ saturated solution of ammonium sulfate at $\mathrm{pH}$ 7.2. The collected pellets were partially purified by dialysis method. The dialysate was further purified by column chromatography using columns packed with Biogel P30 slurry. Purified samples were collected. Purified isolate was estimated for protein by Lowry's method.

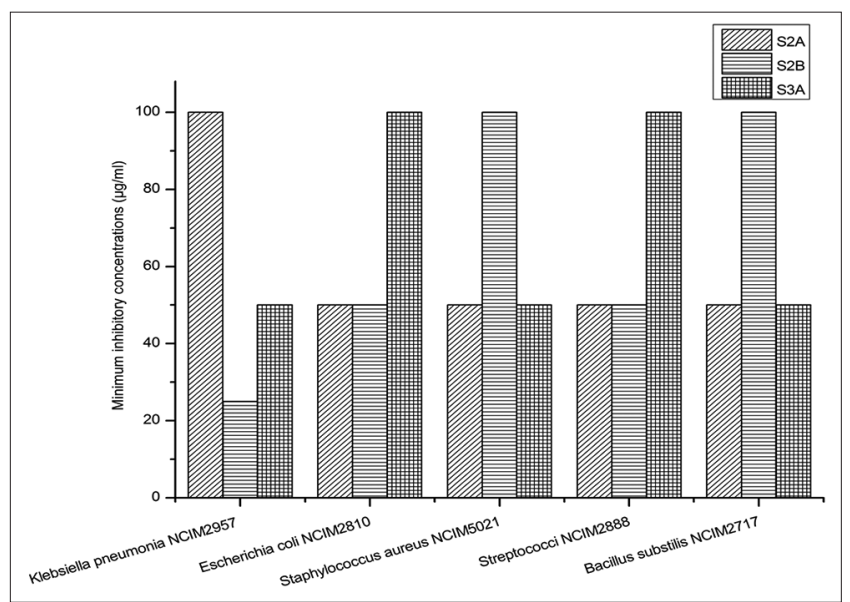

Graph. 1: Determination of minimum inhibitory concentrations of the isolated antibiotic

Table 1: Sensitivity of test organisms against various soils isolate by Agar well diffusion method

\begin{tabular}{|c|c|c|c|c|c|c|}
\hline \multirow{2}{*}{$\begin{array}{l}\text { Soil } \\
\text { isolate }\end{array}$} & \multicolumn{4}{|c|}{ Gram-negative bacteria } & \multicolumn{2}{|l|}{ Gram-positive bacteria } \\
\hline & $\begin{array}{l}\text { Klebsiella } \\
\text { pneumonia NCIM } \\
2957\end{array}$ & $\begin{array}{l}\text { Escherichia coli } \\
\text { NCIM } 2810\end{array}$ & $\begin{array}{l}\text { Staphylococcus aureus } \\
\text { NCIM } 5021\end{array}$ & $\begin{array}{l}\text { Pseudomonas } \\
\text { aeruginosa NCIM } 2957\end{array}$ & $\begin{array}{l}\text { Streptococci sp. NCIM } \\
2888\end{array}$ & $\begin{array}{l}\text { Bacilus substilis } \\
\text { NCIM } 2717\end{array}$ \\
\hline S1A & - & - & - & - & - & - \\
\hline S1B & - & - & - & - & - & - \\
\hline S2A & - & +++ & - & - & - & +++ \\
\hline S2C & - & - & - & - & & - \\
\hline S2AA & - & - & - & - & - & - \\
\hline S3A & +++ & - & - & - & +++ & - \\
\hline
\end{tabular}

+++: Better inhibition, ++: Good inhibition, +: Moderate inhibition, -: No inhibition 
Table 2: Sensitivity of test organisms against various soils isolate by disc diffusion method

\begin{tabular}{|c|c|c|c|c|c|c|}
\hline \multirow{2}{*}{$\begin{array}{l}\text { Soil } \\
\text { isolate }\end{array}$} & \multicolumn{4}{|l|}{ Gram-negative bacteria } & \multicolumn{2}{|c|}{ Gram-positive bacteria } \\
\hline & $\begin{array}{l}\text { Klebsiella pneumonia } \\
\text { NCIM } 2957\end{array}$ & $\begin{array}{l}\text { Escherichia coli } \\
\text { NCIM } 2810\end{array}$ & $\begin{array}{l}\text { Staphylococcus aureus } \\
\text { NCIM } 5021\end{array}$ & $\begin{array}{l}\text { Pseudomonas } \\
\text { aeruginosa NCIM } 2957\end{array}$ & $\begin{array}{l}\text { Streptococci } \\
\text { NCIM } 2888\end{array}$ & $\begin{array}{l}\text { Bacilus substilis } \\
\text { NCIM } 2717\end{array}$ \\
\hline S1A & - & - & - & - & - & - \\
\hline S1B & - & - & - & - & - & - \\
\hline S2A & + & + & +++ & + & + & - \\
\hline S2B & ++ & ++ & +++ & +++ & ++ & + \\
\hline S2C & - & - & - & - & - & - \\
\hline S2AA & - & - & - & - & - & - \\
\hline S3A & + & ++ & ++ & ++ & + & ++ \\
\hline
\end{tabular}

+++: Better inhibition, ++: Good inhibition, +: Moderate inhibition, -: No inhibition

Table 3: Morphological characterization

\begin{tabular}{lll}
\hline Nutrient agar & S2A & S2B \\
\hline Nutrient agar plate & & S3A \\
Plan & Circular & Flat \\
Profile & Flat & Serrate \\
Margin & Serrate & Pale white \\
Color & Pale white & Irregular \\
Surface nature & Irregular & colonies \\
& colonies & Serrate \\
Nutrient agar slant & & Large \\
Abundance of growth & Moderate & Green \\
Pigmentation & Pale green & Trregular \\
Opacity & Translucent & Translucent \\
Form & Effuse & Modfuse \\
\hline
\end{tabular}

Nutrient broth: The uniform and fine turbidity growth of all three isolates (S2A, S2B, S3A) were seen in nutrient broth cultures

Table 4: Microscopical characterization

\begin{tabular}{lll}
\hline Bacterial strains & Gram's-staining & Motility test \\
\hline S2A & $+v e$ & Motile \\
S2B & $-v e$ & Motile \\
S3A & $+v e$ & Motile \\
\hline
\end{tabular}

+ve: Gram-positive, -ve: Gram-negative

Table 5: Bio-chemical characterization

\begin{tabular}{llll}
\hline Name of the test & $\begin{array}{l}\text { Observation } \\
\text { for S2A }\end{array}$ & $\begin{array}{l}\text { Observation } \\
\text { for S2B }\end{array}$ & $\begin{array}{l}\text { Observation } \\
\text { for S3A }\end{array}$ \\
\hline Catalase & + & + & - \\
Methyl red & + & + & - \\
Voges-Proskauer & - & - & + \\
Citrate utilization & - & - & + \\
Urease & + & + & + \\
Indole & + & - & + \\
Gelatinase & + & + & + \\
Oxidase & + & + & + \\
Triple sugar iron & Acid, & Acid, & Alkaline \\
& alkaline, gas & alkaline, gas & production \\
& production & production & \\
\hline +: Indicate positive; - : Indicate negative & &
\end{tabular}

The partially purified extracellular isolate was subjected for antimicrobial activity by Agar well plate method and was found to have good inhibitory effect on the growth of the pathogenic microorganisms. The efficacy of antibiotic produced by soil isolates against the test organism has been shown in Table 6. The isolate was further tested for antimicrobial activity by performing the MIC test, and the results are tabulated as shown in Graph 1. Further, 16S rRNA study of the genomic DNA extracted from isolate S2B conforms it belongs to Pseudomonas species which is named as Pseudomonas putida 2435.

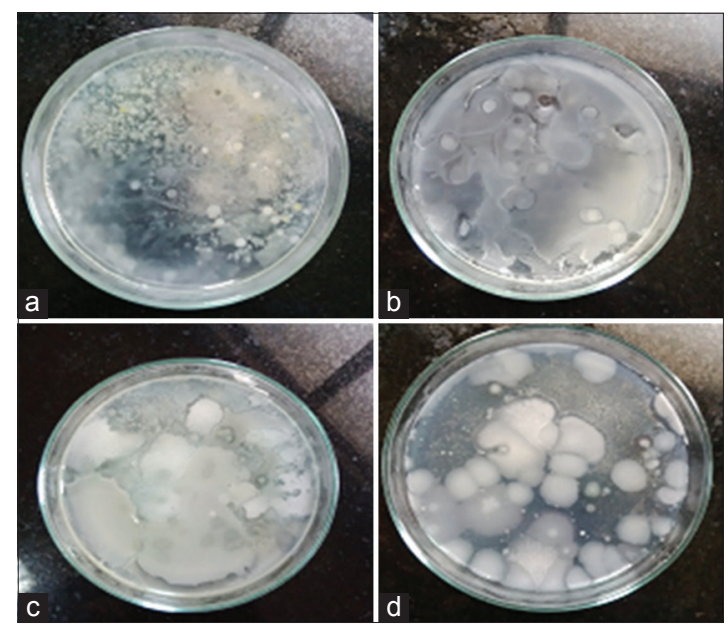

Fig. 1: Crowded plate technique: Soil samples 1, 2, 3 and 4 in plate a, b, c, d, respectively

Antibiotics isolated may be bactericidal or bacteriostatic in nature. Since soil harbors a wide range of microflora, there is a possibility of finding out new species and strains.

\section{S rRNA studies}

S2B isolate having good inhibitory activity on test microorganisms was selected for 16S $r$ RNA sequence studies and the sequence given below in Fig. 3: According to the $16 \mathrm{~S} r$ RNA sequence studies, S2B isolate was found to be: P. putida 2435 .

\section{CONCLUSION}

The research work was concluded that the three isolates showed good antibacterial activity against Gram-positive and Gram-negative bacteria. The S2B isolate was confirmed to P. putida 2435 by $16 \mathrm{~S}$ rRNA studies. 
Table 6: Determination of antimicrobial activity of partially purified samples

\begin{tabular}{|c|c|c|c|c|c|c|}
\hline Sample & $\begin{array}{l}\text { Klebsiella pneumonia } \\
\text { NCIM } 2957\end{array}$ & $\begin{array}{l}\text { Escherichia coli } \\
\text { NCIM } 2810\end{array}$ & $\begin{array}{l}\text { Staphylococcus aureus } \\
\text { NCIM } 5021\end{array}$ & $\begin{array}{l}\text { Pseudomonas aeruginosa } \\
\text { NCIM } 2957\end{array}$ & $\begin{array}{l}\text { Streptococci } \\
\text { NCIM } 2888\end{array}$ & $\begin{array}{l}\text { Bacilus substilis } \\
\text { NCIM } 2717\end{array}$ \\
\hline S2A & ++ & ++ & + & ++ & ++ & ++ \\
\hline S2B & ++ & ++ & +++ & +++ & ++ & ++ \\
\hline S3A & ++ & ++ & ++ & ++ & ++ & + \\
\hline
\end{tabular}

+++: Better inhibition, ++: Good inhibition, +: Moderate inhibition

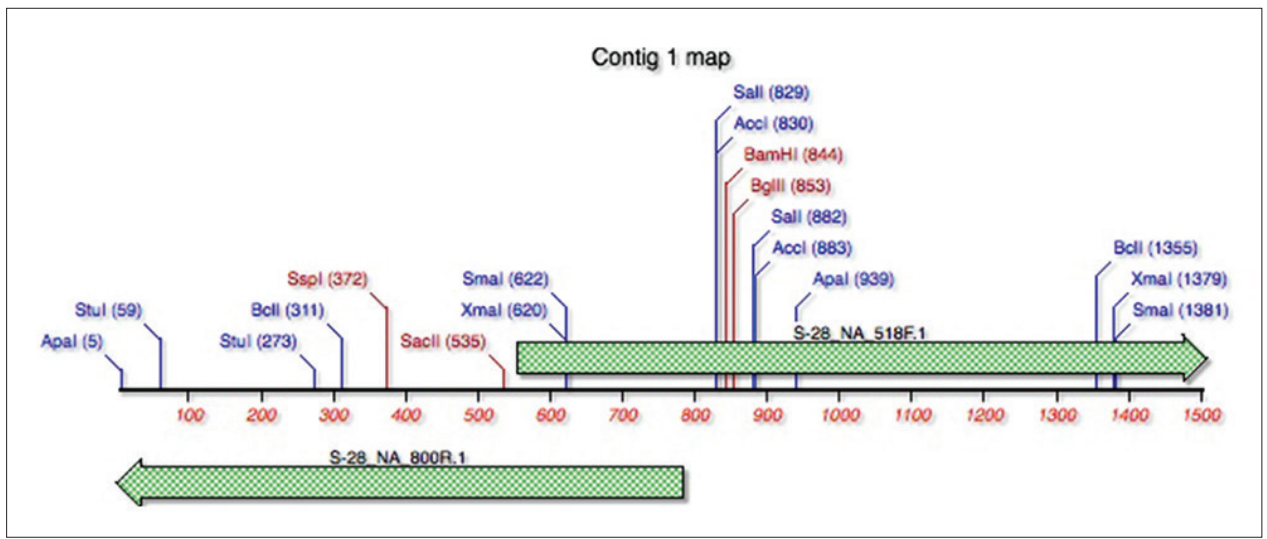

Fig. 2: 16S rRNA sequence for the SA2 bacteria

This strain may be having unique antibiotic characteristics compared to other antibiotics, and this can be confirmed by further structural elucidation and sequencing. In future, the quality, novelty and commercial value of this antibiotic can be explored. The strain $P$. putida 2435 can be subjected to strain improvement and enhancement of the antibiotic production by medium optimization process

\section{REFERENCES}

1. Kaur S, Kaur J, Pankaj PP. Isolation and characterization of antibiotic producing microorganisms from soil samples of a certain area of Punjab region of India. Int J Pharm Clin Res 2014;6(4):312-5.

2. Singh AP, Mishra S. Isolation and biochemical characterization of antibiotic producing microorganism from waste soil samples of certain industrial areas of India. IOSR J Pharm Biol Sci 2013;5(6):80-9.

3. Abbas S, Senthilkumar R, Arjunan S. Isolation and molecular characterization of the microorganism producing novel antibiotics from the soil sample. Eur J Exp Biol 2014;4(5):149-55.

4. Lee YS, Lee HY, Lee CH, Park HS. Isolation of antibiotic-producing bacteria antagonistic to Fusarium oxysporium from sesame-growing soils and evaluation of their antifungal activity. J Microbiol Biotechnol 1995;5(6):46-352.

5. Chaudhary HS, Yadav J, Shrivastava AR, Singh S, Singh AK, Gopalan N. Antibacterial activity of actinomycetes isolated from different soil samples of Sheopur (A city of central India). J Adv Pharm Technol Res 2013;4(2):118-23.

6. Dwivedi S, Thakkar R, Upadhyay V, Kumar S. Isolation and characterization of actinomycetes producing antimicrobial substance against human pathogenic bacteria. J Pharm Res 2011;2(4):4066-8.

7. Kokare C. Identification of morphological characterization of bacteria. Pharm Microbiol Princ Appl 2005;7:4-7.
8. Pepper IL, Garba CP. Environmental Microbiology. Vol. 2. London: Elsevier Academic Press; 2004. p. 37-49.

9. Sundararaj T. Motility tests for the isolated microorganism. Taramani, India: Dr. A. L. Mudaliar Post Graduate Institute of Basic Medical Sciences, University of Madras; 1995. p. 52-3.

10. Nonomura $\mathrm{H}$. The key for classification and identification of 458 species of the Streptomycetes included in ISP. J Ferment Technol 1974;52:107-14.

11. Krithika S, Chellaram C. Isolation, screening and characterization of chitinase producing bacteria from marine water. Int J Pharm Pharm Sci 2016;8:34-6.

12. Abirami V, Meenakshi SA, Kanthymathy K, Bharathidasan R, Mahalingam R, Panneerselvam A. Partial purification and characterization of an extracellular protease from Penicillium janthinellum and Neurospora crassa. Eur J Exp Biol 2011;1(3):114-23.

13. Verma M. Antimicrobial screening of the leaf extracts of Bacopa monnieri (L) Pennell. IJCPR 2016;8:21-3.

14. Edwards U, Rogall T, Blöcker H, Emde M, Böttger EC. Isolation and direct complete nucleotide determination of entire genes. Characterization of a gene coding for $16 \mathrm{~S}$ ribosomal RNA. Nucleic Acids Res 1989;17(19):7843-53.

15. Castresana J. Selection of conserved blocks from multiple alignments for their use in phylogenetic analysis. Mol Biol Evol 2000;17(4):540-52.

16. Dereeper A, Guignon V, Blanc G, Audic S, Buffet S, Chevenet F, et al. Phylogeny.fr: Robust phylogenetic analysis for the non-specialist. Nucleic Acids Res 2008;36(1):W465-9.

17. Edgar RC. MUSCLE: Multiple sequence alignment with high accuracy and high throughput. Nucleic Acids Res 2004;32(5):1792-7.

18. Talavera G, Castresana J. Improvement of phylogenies after removing divergent unambiguously aligned blocks from protein sequence alignments. Syst Biol 2007;56(4):564-77. 